\title{
Long-Term Persistence of Hepatitis A Antibodies in Pediatric HIV-Infected Patients after Primary Immunization: Association with Immunological Profile and Response to Revaccination
}

Aida de Fátima Thomé Barbosa Gouvêa, Maria Isabel de Moraes-Pinto, Maristela Miyamoto, Silvana Duarte Pessoa, Daisy Maria Machado and Regina Célia de Menezes Succi*

Department of Pediatrics - Escola Paulista de Medicina - Universidade Federal de São Paulo, Sao Paulo, SP, Brazil

\begin{abstract}
Background: We analyzed the persistence of hepatitis A virus (HAV) antibodies 7 years after primary immunization in pediatric HIV-positive patients and its association with the immunological profile.

Methods: 29 vertically HIV-infected adolescents (median age, 12.9 years) were enrolled. All of them had been HAV-vaccinated with two HAV vaccine doses 7 years before and all had seroconverted. HAV antibodies were measured by electrochemiluminescence. Lymphocyte immunophenotyping was performed by flow cytometry. Adolescents who lost HAV antibodies were revaccinated.

Results: $23 / 29$ patients $(79.3 \%$ ) persisted HAV seropositive (HAV antibodies $\geq 20 \mathrm{mlU} / \mathrm{mL}$ ) 7 years after primary immunization. Age, gender, clinical progression of HIV infection, median viral load, and antiretroviral therapy were similar between those who persisted HAV seropositive and those who lost seropositivity. HIV adolescents who lost HAV antibodies had lower median CD4+ T cells $/ \mathrm{mm}^{3}$ (200 vs. $\left.634, p=0.004\right)$, lower median B cells $/ \mathrm{mm}^{3}(103$ vs. 335 , $p<0.001)$, lower median NK cells $/ \mathrm{mm}^{3}$ (67 vs. 209, $\left.p=0.002\right)$, lower median percentage of naive CD4+ T cells $(20 \%$ vs. $30 \%, p=0.026)$, lower median percentage of naive $B$ cells $(52 \%$ vs. $68 \%, p=0.009)$, higher median percentage of activated memory B cells ( $19 \%$ vs. $7 \%, p=0.004)$, higher median percentage of activated CD $8+$ T cells $(51 \%$ vs. $22 \%$, $p=0.002)$, and higher median percentage of exhausted memory B cells $(23 \%$ vs. $8 \%, p=0.031)$ than HAV-positive adolescents. $83.3 \%$ adolescents responded to revaccination.
\end{abstract}

Conclusion: Persistence of HAV antibodies occurred in $79.3 \%$ of patients. Both antibody maintenance and response to revaccination are closely associated with low immune activation and adequate $C D 4+T$ and $B$ cell levels.

Keywords: Hepatitis A; HIV; Revaccination; Immunologic markers; AIDS

\section{Introduction}

Vertically HIV-infected patients need to be monitored for antibody persistence after primary immunization, both because of low immune response and the accelerate decay of antibodies after vaccination [1]. This loss of antibodies can contribute to increase the pool of susceptible adolescents who can become sufficiently numerous to sustain the transmission of vaccine-preventable diseases and jeopardize control efforts [2].

In recent years, improvements in sanitary conditions have contributed to a decrease in hepatitis A endemicity in the southeastern region of Brazil, changing it from moderate to low levels [3]. In this part of Brazil, prevalence of hepatitis A in children aged 5 to 19 years is now less than $25 \%$ [3]. The young reach adulthood susceptible to this disease, and in this age group, hepatitis A may be more severe [4].

Hepatitis A vaccine, although not provided to all children in the Brazilian Immunization Program, is available for specific population groups, including HIV-infected individuals [5].

Between March and November 2002, a group of 32 HIV-infected children and $27 \mathrm{HIV}$-exposed and uninfected children were included to receive two doses of HAV vaccine, with $100 \%$ of them experiencing seroconversion with high antibody levels [6]. This study had no children with severe HIV-related symptoms (class C) or low CD4+ T cells (category 3 ) according to the CDC criteria $[7,8]$.

The aim of the present study was to analyze the persistence of HAV antibodies 7 years after primary immunization in HIV- infected adolescents and its association with clinical, virological, and immunological measures and to analyze the response to revaccination in patients who lost HAV seropositivity.

\section{Patients and Methods}

This research was approved by the Ethics Committee of the Universidade Federal de São Paulo, Brasil, and written informed consent was obtained from parents or guardians. Between December 2009 and January 2010, 29 of these previously HAV-vaccinated HIVinfected adolescents were enrolled. All of them were HIV-infected through vertical transmission.

\section{Subjects}

To be included in the study, the adolescents must have received two doses of HAV vaccine (Havrix; Glaxo SmithKline Beecham, Rixensart,

*Corresponding author: Regina Célia de Menezes Succi, Rua Pedro de Toledo, 928, Vila Clementino, São Paulo /SP, 04039-003 São Paulo/SP, Brazil, Tel: 5511-5571-6664; Fax: 55-11-5572-8922; E-mail: succi@picture.com.br

Received February 20, 2014; Accepted March 22, 2014; Published March 31, 2014

Citation: Gouvêa AdFTB, de Moraes-Pinto MI, Miyamoto M, Pessoa SD, Machado DM, et al. (2014) Long-Term Persistence of Hepatitis A Antibodies in Pediatric HIV-Infected Patients after Primary Immunization: Association with Immunological Profile and Response to Revaccination. J AIDS Clin Res 5: 295. doi:10.4172/21556113.1000295

Copyright: (C) 2014 Gouvêa AdFTB, et al. This is an open-access article distributed under the terms of the Creative Commons Attribution License, which permits unrestricted use, distribution, and reproduction in any medium, provided the original author and source are credited. 
Citation: Gouvêa AdFTB, de Moraes-Pinto MI, Miyamoto M, Pessoa SD, Machado DM, et al. (2014) Long-Term Persistence of Hepatitis AAntibodies in Pediatric HIV-Infected Patients after Primary Immunization: Association with Immunological Profile and Response to Revaccination. J AIDS Clin Res 5: 295. doi:10.4172/2155-6113.1000295

Page 2 of 6

Belgium) between March and November 2002. The data were collected by review of medical records since admission to the Outpatient Pediatric AIDS Clinic. Clinical and immunological categories of HIV infection were determined according to the 1994 Centers for Disease Control and Prevention (CDC) revised classification [7,8].

Nutritional assessment was performed by calculating the $z$ score (E/I and Body Mass Index for age) using data from the World Health Organization as a reference [9].

A blood sample from a healthy adolescent was used to compare cell subpopulations in cytometric flow chart.

\section{Study design}

The patients were included in a longitudinal, prospective, and interventional study. Among the $32 \mathrm{HIV}$-infected patients who received primary immunization in 2002, one had received a third dose of HAV vaccine in 2009 and was excluded. Two patients moved to another clinic so that $29 \mathrm{HIV}$-infected patients were included in the study. HIVinfected adolescents with antibodies $\geq 20 \mathrm{mlU} / \mathrm{mL}$ were considered seropositive to hepatitis A [10].

\section{Hepatitis A vaccine}

Nonimmune adolescents were revaccinated with two intramuscular doses of hepatitis A vaccine (Havrix ${ }^{\star}$ ) administered with a 6-month interval between doses.

\section{Immunological profiles and serological tests}

At the beginning of the study, a $10 \mathrm{~mL}$ blood sample was drawn by peripheral venous puncture from each individual for immunological assessment and HAV testing. Another $5 \mathrm{~mL}$ blood sample was drawn from nonimmune subjects by peripheral venous puncture 30 days after the first and second doses of the revaccination for the HAV serological tests.

All samples were tested for HAV total antibodies by electrochemiluminescence using the Elecsys Anti-HAV reagent kit (Roche Diagnostics, Indianapolis, IN, USA). Peripheral blood mononuclear cells were assessed by 6-color flow cytometry from whole blood sample collected on the same day (FACSCanto, BD Biosciences, Franklin Lakes, NY, USA) after cell staining using a lyse-wash protocol and analyzed using Flow JO software (TriStar, Ashland, TN, USA). Isotypic controls (rat IgG2a-PE, IgG 2a-PerCP, IgG1-Pe-Cy7, IgG1APC, IgG1-FITC, IgG1-PE, and IgG1-PerCP), all from BD Biosciences (San Jose, CA, USA), were used to evaluate nonspecific staining. The number of cells per cubic milliliter of blood was obtained using the lymphocyte counts from the complete blood count from the same venous puncture.

CD4+ and CD8+ T lymphocytes: The markers used to assess the subpopulation within the CD4+ (CD3-APC Cy 7- and CD4APC-labeled) and CD8+ (CD3-APC Cy 7- and CD8-APC-labeled) populations were CD45RA-FITC and CCR7-PE (BD Biosciences, San Jose, USA). In both CD4+ and CD8+ populations, the "naive" cells were CD45RA+CCR7+. The "central memory" cells were CD45RACCR7+, and the "effector memory" cells were CD45RA-CCR7-. The "terminally differentiated memory" cells, more abundantly seen among CD8+ cells than in the CD4+ cohort, were CD45RA+CCR7-

B cells: B lymphocytes were identified as CD3-CD19+ cells (CD3 APC Cy 7- and CD19 PerCP-labeled), and their maturation subsets were evaluated using CD10 PE Cy7, CD21 APC, and CD27 PE. Immature transitional cells were CD3-CD19+CD10+. Naive B cells were CD3-CD19+CD10-CD21+CD27-. Resting memory cells were CD3-CD19+CD10-CD21+CD27+. Activated memory cells were CD3-CD19+CD10-CD21-CD27+. Exhausted memory cells were CD3-CD19+CD10-CD21-CD27- [11].

NK cells: Natural killer (NK) cells were quantified by the CD45+CD3-CD56+CD16+ phenotype (CD3 APC-, CD45 PerCP-, and CD16 PE/CD56 PE-labeled).

T and B lymphocytes and NK cell activation: CD4+ and CD8+ T cell activation was evaluated by CD38+HLA-DR+ expression (CD38 PE Cy7- and HLA-DR PerCP-labeled). The activation of B cells and NK cells was assessed by CD38+ expression (CD38 FITC-labeled).

HIV viral load: HIV RNA (viral load) was quantified using realtime polymerase chain reaction and the Cobas Amplicor HIV-1 Monitor kit (Roche Diagnostic Systems, Basel, Switzerland) or b-DNA using the Bayer Versant HIV-1 RNA 3.0 kit (Bayer, Tarrytown, NY, USA).

\section{Statistical analysis}

Categorical variables were assessed by Fisher's exact test. Quantitative variables were tested using the Mann-Whitney test. The results were considered statistically significant at $p<0.05$. Statistical analyses were performed using the Statistical Package for Social Science 16.0 (SPSS, Chicago, IL, USA).

\section{Results}

Significant hepatitis A antibody decay was observed in the 29 HIV-infected adolescents from 30 days after primary immunization $(1990 \mathrm{mIU} / \mathrm{mL})$ compared to 7 years after primary immunization $(113$ $\mathrm{mIU} / \mathrm{mL} ; p<0.0001$; Figure 1A). Twenty-three of the patients $(79.3 \%)$ maintained HAV antibodies $\geq 20 \mathrm{mlU} / \mathrm{mL} 7$ years after primary immunization, and six (20.7\%) lost antibodies.

Figure 1B shows HAV antibodies among the $23 \mathrm{HIV}$-infected adolescents who remained seropositive and the six individuals who lost HAV antibodies. Figure 1B also shows the response of these six individuals after the first and second doses of HAV revaccination. Four

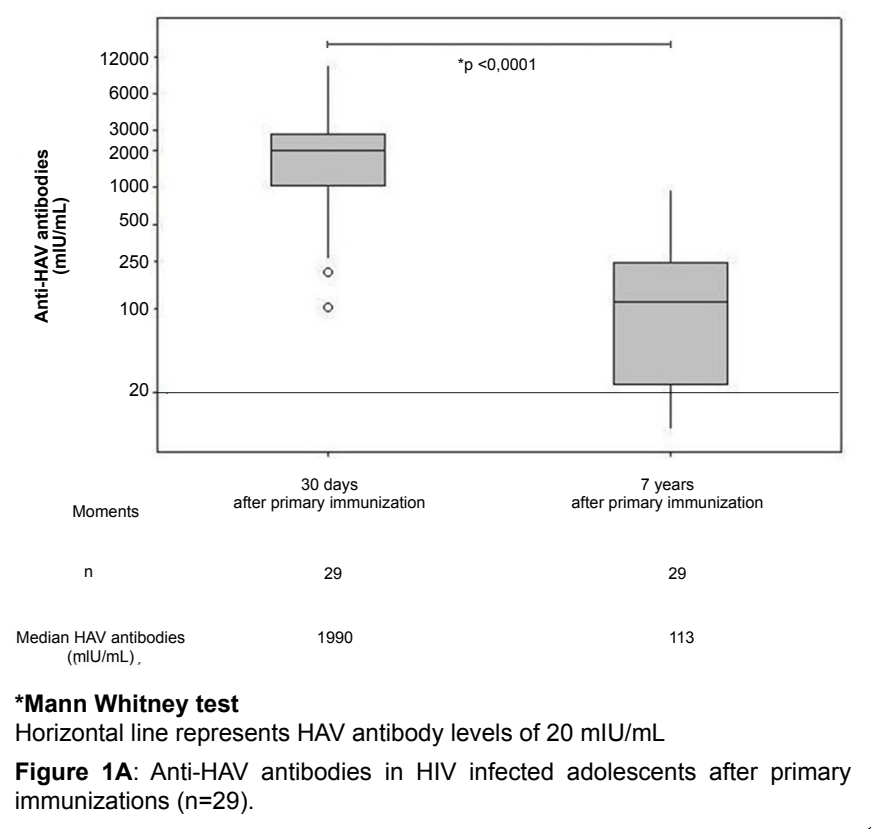


Citation: Gouvêa AdFTB, de Moraes-Pinto MI, Miyamoto M, Pessoa SD, Machado DM, et al. (2014) Long-Term Persistence of Hepatitis AAntibodies in Pediatric HIV-Infected Patients after Primary Immunization: Association with Immunological Profile and Response to Revaccination. J AIDS Clin Res 5: 295. doi:10.4172/2155-6113.1000295

Page 3 of 6

out of six patients responded with HAV antibodies above $20 \mathrm{mIU} / \mathrm{mL}$ with one HAV vaccine dose. A second dose was necessary for a fifth patient to attain antibodies over $20 \mathrm{mIU} / \mathrm{mL}$. Median HAV antibody levels were far below those attained by the 29 patients after primary HAV immunization seven years before $(1990 \mathrm{mIU} / \mathrm{mL})$; however, 4

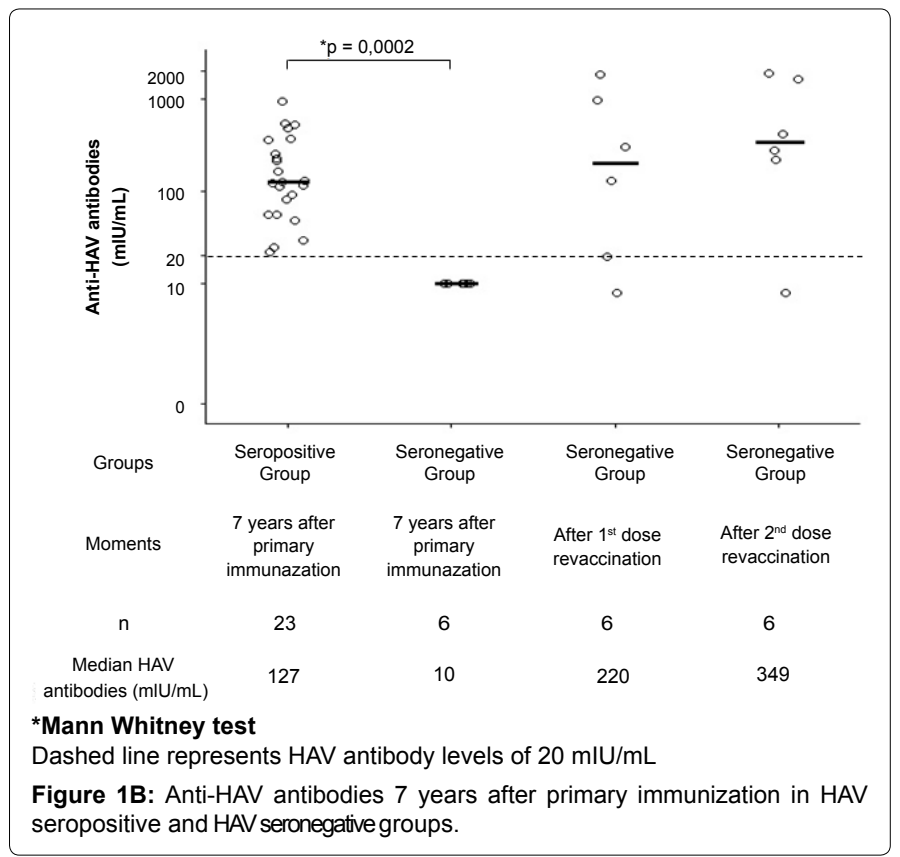

out of the 6 patients who were revaccinated had already shown a less intense response to HAV vaccine after primary immunization, with HAV antibody levels below $300 \mathrm{mIU} / \mathrm{mL}$.

The HAV seropositive and seronegative groups were assessed for clinical, immunological, and virological aspects during the clinical follow-up to determine the factors that differentiated them. Age, gender, the clinical progression of HIV infection, median log viral load, antiretroviral therapy use, and nutritional status were similar in both groups. However, the median nadir of CD4+ T cells was significantly higher in the HAV seropositive group (Table 1).

The immunophenotypic assessment of the lymphocyte profile showed that the seropositive group had higher CD4+ T cell numbers, higher naive CD4+ T cells, a lower percentage of peripheral memory cells, and a lower percentage of activated CD4+ T cells. With regard to CD8+ T cells, the seropositive group had a lower percentage of activated CD8+ T cells. The seropositive group had higher B cell numbers, higher naive $B$ cell percentages, and lower activated $B$ cell and exhausted memory B cell percentages. The seropositive group had higher NK cell numbers (Table 2).

Figure 2 illustrates the typical flow cytometry cell profiles of four adolescents: (A) a healthy non-HIV-infected adolescent, (B) a HIVinfected patient who maintained hepatitis A antibodies after 7 years, (C) a HIV-infected patient who did not have hepatitis A antibodies after 7 years but responded to the two doses of revaccination with high levels of antibodies (over 1,000 $\mathrm{mIU} / \mathrm{mL}$ ), and (D) a HIV-infected patient from the HAV seronegative group who did not respond to the revaccination.

\begin{tabular}{|c|c|c|c|}
\hline Characterization of HIV-infected patients & $\begin{aligned} \text { Anti-HAV } & \geq 20 \mathrm{mlU} / \mathrm{mL} \\
(\mathrm{n}=23) & \end{aligned}$ & $\begin{array}{l}\text { Anti-HAV }<20 \mathrm{mlU} / \mathrm{mL} \\
(\mathrm{n}=6)\end{array}$ & $\mathbf{p}$ \\
\hline $\begin{array}{l}\text { Median age at study inclusion (years) } \\
\text { (range) }\end{array}$ & $\begin{array}{c}12.4 \\
(9.7,16.8)\end{array}$ & $\begin{array}{c}13.5 \\
(10.9,16.2)\end{array}$ & $0.450^{*}$ \\
\hline Median age at primary HAV immunization (years) (range) & $\begin{array}{c}5.13 \\
(1.92,9.32)\end{array}$ & $\begin{array}{c}6.01 \\
(3.18,8.96)\end{array}$ & $0.628^{*}$ \\
\hline $\begin{array}{l}\text { Median age at beginning of ARV } \\
\text { (years) (range) }\end{array}$ & $\begin{array}{c}1.73 \\
(0.27,5.63)\end{array}$ & $\begin{array}{c}3.18 \\
(1.67,4.34)\end{array}$ & $0.196^{*}$ \\
\hline $\begin{array}{l}\text { Female } \\
(\%)\end{array}$ & $\begin{array}{c}11 \\
(47.8)\end{array}$ & $\begin{array}{c}3 \\
(50)\end{array}$ & $0.924^{\dagger}$ \\
\hline $\begin{array}{l}Z \text { score } \mathrm{H} / \mathrm{A} \\
\text { (range) }\end{array}$ & $\begin{array}{c}-0.88 \\
(-2.21,+1.06)\end{array}$ & $\begin{array}{c}-0.40 \\
(-1.51,+1.44)\end{array}$ & $0.205^{*}$ \\
\hline $\begin{array}{l}Z \text { score BMI } \\
\text { (range) }\end{array}$ & $\begin{array}{c}-0.10 \\
(-2.6,+1.7)\end{array}$ & $\begin{array}{c}-0.36 \\
(-2.64,+0.89)\end{array}$ & $0.726^{*}$ \\
\hline $\begin{array}{l}\text { Clinical category } \\
\text { N/A/B }(\%) \\
\text { C (\%) }\end{array}$ & $\begin{array}{c}20(87.0) \\
3(13.0)\end{array}$ & $\begin{array}{l}5(83.3) \\
1(16.7)\end{array}$ & $0.819^{\dagger}$ \\
\hline $\begin{array}{l}\text { Immunologic category } \\
1 / 2(\%) \\
3(\%) \\
\end{array}$ & $\begin{array}{c}21(91.3) \\
2(8.7)\end{array}$ & $\begin{array}{l}4(66.7) \\
2(33.3)\end{array}$ & $0.119^{\dagger}$ \\
\hline $\begin{array}{l}\text { Median CD4+ T cells before starting ART } \\
\text { (range) }\end{array}$ & $\begin{array}{c}1532 \\
(315,4245)\end{array}$ & $\begin{array}{c}720 \\
(520,1580)\end{array}$ & $0.058^{*}$ \\
\hline $\begin{array}{l}\text { Median nadir CD4+ T cells count (cells/mm3) } \\
\text { (range) }\end{array}$ & $\begin{array}{c}485 \\
(140,1179)\end{array}$ & $\begin{array}{c}200 \\
(5,559)\end{array}$ & $0.019^{*}$ \\
\hline $\begin{array}{l}\text { Median current log VL (copies } / \mathrm{mL} \text { ) } \\
\text { (range) }\end{array}$ & $\begin{array}{c}3.0 \\
(1.0,4.97)\end{array}$ & $\begin{array}{c}4.0 \\
(2.16,5.7)\end{array}$ & $0.067^{*}$ \\
\hline $\begin{array}{l}\text { Median log VL before starting ART } \\
\text { (range) }\end{array}$ & $\begin{array}{c}5.2 \\
(4.1,7.1)\end{array}$ & $\begin{array}{c}4.9 \\
(3.3,5.2)\end{array}$ & $0.216^{*}$ \\
\hline Number of patients with undetectable current VL (\%) & $6 / 23(26)$ & $0 / 6(0)$ & $0.160^{+}$ \\
\hline $\begin{array}{l}\text { Number of patients starting ART aged } \leq 1 \text { year }(\%) \\
\text { Number of patients without ART at primary immunization (\%) }\end{array}$ & $\begin{array}{c}8 / 23(34.7) \\
0 / 23(0)\end{array}$ & $\begin{array}{c}0 / 6(0) \\
1 / 6(16.6)\end{array}$ & $\begin{array}{l}0.089^{\dagger} \\
0,207^{\dagger}\end{array}$ \\
\hline Number of patients without ART at the current study (\%) & $4 / 23(17.4)$ & $3 / 6(50.0)$ & $0.096^{\dagger}$ \\
\hline
\end{tabular}

* Mann Whitney test, ${ }^{\dagger}$ Fisher's exact test; ART: Antiretroviral therapy; VL: HIV viral load

Table 1: Clinical, immunological and virological aspects of HIV-infected patients from HAV seropositive (Anti-HAV $\geq 20 \mathrm{mIU} / \mathrm{mL})$ and HAV seronegative 
Citation: Gouvêa AdFTB, de Moraes-Pinto MI, Miyamoto M, Pessoa SD, Machado DM, et al. (2014) Long-Term Persistence of Hepatitis AAntibodies in Pediatric HIV-Infected Patients after Primary Immunization: Association with Immunological Profile and Response to Revaccination. J AIDS Clin Res 5: 295. doi:10.4172/2155-6113.1000295

Page 4 of 6

\begin{tabular}{|c|c|c|c|}
\hline Cell subset & $\begin{array}{l}\text { Anti-HAV } \geq 20 \mathrm{mlU} / \mathrm{mL} \\
\quad(n=23)\end{array}$ & $\begin{array}{c}\text { Anti-HAV }<20 \mathrm{mlU} / \mathrm{mL} \\
\qquad(\mathrm{n}=6)\end{array}$ & $\begin{array}{l}\text { Mann Whitney test } \\
(p)\end{array}$ \\
\hline $\begin{array}{l}\text { CD4+ T cells }\left(\text { cells } / \mathrm{mm}^{3}\right) \\
\text { (range) }\end{array}$ & $\begin{array}{c}634.1 \\
(188.1,1295.0)\end{array}$ & $\begin{array}{c}200.4 \\
(8.7,736.7)\end{array}$ & 0.004 \\
\hline $\begin{array}{l}\text { Naïve: CD45RA+CCR7+ (\%) } \\
\text { (range) }\end{array}$ & $\begin{array}{c}29.9 \\
(9.7,61.9)\end{array}$ & $\begin{array}{c}20 \\
(6.9,30.3)\end{array}$ & 0.026 \\
\hline $\begin{array}{l}\text { Central Memory: CD45RA-CCR7+ (\%) } \\
\text { (range) }\end{array}$ & $\begin{array}{c}9.63 \\
(3.81,18.1)\end{array}$ & $\begin{array}{c}7.13 \\
(1.01,17.9)\end{array}$ & 0.414 \\
\hline $\begin{array}{l}\text { Effector Memory: CD45RA-CCR7- (\%) } \\
\text { (range) }\end{array}$ & $\begin{array}{c}31.6 \\
(14.4,60.3)\end{array}$ & $\begin{array}{c}50.2 \\
(28.1,68.1)\end{array}$ & 0.014 \\
\hline $\begin{array}{l}\text { Terminally Differentiated: CD45RA+CCR7- (\%) } \\
\text { (range) }\end{array}$ & $\begin{array}{c}21.7 \\
(12.2,55.1)\end{array}$ & $\begin{array}{c}18.6 \\
(6.8,63.9)\end{array}$ & 0.511 \\
\hline $\begin{array}{l}\text { Activated CD3+CD4+CD38+ HLADR+(\%) } \\
\text { (range) }\end{array}$ & $\begin{array}{c}12.6 \\
(7.9,26.0)\end{array}$ & $\begin{array}{c}24.8 \\
(10.6,49.0)\end{array}$ & 0.054 \\
\hline $\begin{array}{l}\text { CD8+ T cells }\left(\text { cells } / \mathrm{mm}^{3}\right) \\
\text { (range) }\end{array}$ & $\begin{array}{c}929.4 \\
(529.9,1852.8)\end{array}$ & $\begin{array}{c}375.6 \\
(104.0,1633.5)\end{array}$ & 0.102 \\
\hline $\begin{array}{l}\text { Naïve: CD45RA+CCR7+ (\%) } \\
\text { (range) }\end{array}$ & $\begin{array}{c}17.2 \\
(8.6,52.4)\end{array}$ & $\begin{array}{c}5.6 \\
(2.2,39.1)\end{array}$ & 0.080 \\
\hline $\begin{array}{l}\text { Central Memory: CD45RA-CCR7+ (\%) } \\
\text { (range) }\end{array}$ & $\begin{array}{c}1.2 \\
(0,2.8)\end{array}$ & $\begin{array}{c}1.8 \\
(1,4.2)\end{array}$ & 0.694 \\
\hline $\begin{array}{l}\text { Effector Memory: CD45RA-CCR7- (\%) } \\
\text { (range) }\end{array}$ & $\begin{array}{c}44.6 \\
(1.7,66)\end{array}$ & $\begin{array}{c}62.6 \\
(33.7,78.0)\end{array}$ & 0.080 \\
\hline $\begin{array}{l}\text { Terminally Differentiated: CD45RA+CCR7- (\%) } \\
\text { (range) }\end{array}$ & $\begin{array}{c}28.5 \\
(17.1,89.6)\end{array}$ & $\begin{array}{c}27.4 \\
(13.8,35.2)\end{array}$ & 0.384 \\
\hline $\begin{array}{l}\text { Activated CD3+CD8+CD38+ HLADR+ (\%) } \\
\text { (range) }\end{array}$ & $\begin{array}{c}22.0 \\
(7.5,59.3)\end{array}$ & $\begin{array}{c}51.4 \\
(30.8,68.5)\end{array}$ & 0.002 \\
\hline $\begin{array}{l}\text { B cells: CD } 19+\text { cells }\left(\text { cells } / \mathrm{mm}^{3} \text { ) }\right. \\
\text { (range) }\end{array}$ & $\begin{array}{c}334.54 \\
(76.53,632.7)\end{array}$ & $\begin{array}{c}103.21 \\
(6,78,121,4)\end{array}$ & $<0.001$ \\
\hline $\begin{array}{l}\text { Immature Transitional (CD19+CD10+) (\%) } \\
\text { (range) }\end{array}$ & $\begin{array}{c}33.6 \\
(9.2,82.9)\end{array}$ & $\begin{array}{c}31.4 \\
(10.1,69.3)\end{array}$ & 0.655 \\
\hline $\begin{array}{l}\text { Naive (CD21+CD27-) (\%) } \\
\text { (range) }\end{array}$ & $\begin{array}{c}68.2 \\
(37.2,89.5)\end{array}$ & $\begin{array}{c}52.1 \\
(9.7,69.6)\end{array}$ & 0.009 \\
\hline $\begin{array}{l}\text { Resting Memory (CD21+CD27+) (\%) } \\
\text { (range) }\end{array}$ & $\begin{array}{c}13.7 \\
(4.6,36.2)\end{array}$ & $\begin{array}{c}9.8 \\
(4.0,17.4)\end{array}$ & 0.158 \\
\hline $\begin{array}{l}\text { Activated Memory (CD21-CD27+) (\%) } \\
\text { (range) }\end{array}$ & $\begin{array}{c}6.8 \\
(0.7,21.7)\end{array}$ & $\begin{array}{c}18.9 \\
(6.9,32.8)\end{array}$ & 0.004 \\
\hline $\begin{array}{l}\text { Exhausted Memory (CD21-CD27-) (\%) } \\
\text { (range) }\end{array}$ & $\begin{array}{c}8.1 \\
(0.4,31.8)\end{array}$ & $\begin{array}{c}22.6 \\
(7.0,60.7)\end{array}$ & 0.031 \\
\hline $\begin{array}{l}\text { NK cells }\left(\text { cells } / \mathrm{mm}^{3}\right) \\
\text { (range) }\end{array}$ & $\begin{array}{c}209.3 \\
(22.8,429.3)\end{array}$ & $\begin{array}{c}67.3 \\
(35.6,93.9)\end{array}$ & 0.002 \\
\hline $\begin{array}{l}\text { Activated CD3-CD16+/CD56+CD38+ (\%) } \\
\text { (range) }\end{array}$ & $\begin{array}{c}78.5 \\
(49.1,96.1)\end{array}$ & $\begin{array}{c}81.8 \\
(44.7,99.6)\end{array}$ & 0.733 \\
\hline
\end{tabular}

\section{*Mann Whitney test}

Table 2: Median absolute numbers and lymphocyte percentages of HIV-infected adolescents divided according to HAV seropositivity 7 years after primary immunization

We found that the activation markers CD38+ and HLA-DR+ CD8+ T cells were not high in the healthy adolescent $(\mathrm{A})$ and in HIV-infected patient (B). However, in the HIV-infected patients (C) and (D), they were much higher, especially in patient (D) who did not respond to revaccination.

With the exception of the adolescent who did not respond to revaccination, the other three adolescents had comparable numbers and percentages of $\mathrm{CD} 4+\mathrm{T}$ cells. As we assessed the maturation of the CD4+T cells, we noticed that the non-HIV-infected adolescent had a higher naive $\mathrm{CD} 4+\mathrm{T}$ cell percentage. For the others, peripheral memory CD4+ T cells were the predominant subset.

Naive and resting memory B cell percentages were comparable in the healthy adolescent (A) and HIV-infected patient who maintained HAV antibodies (B). By contrast, activated memory and exhausted memory B cells increased in HIV infected patients (C and D), mainly in the patient who did not respond to revaccination (D).

\section{Discussion}

This study showed that $79.3 \%$ (23 of 29) of vertically HIV-infected adolescents maintained HAV antibodies above $20 \mathrm{mIU} / \mathrm{mL} 7$ years after primary immunization. The persistence of HAV antibodies was associated with higher CD4+ T cells (both nadir and absolute numbers), higher $\mathrm{B}$ cells, higher NK cells, and lower immune activation at assessment 7 years after vaccination.

The present study found median HAV antibody levels of $113 \mathrm{mIU} /$ $\mathrm{mL}$ in the $29 \mathrm{HIV}$-infected patients. These results can be compared with those from Bian et al. [12] who found that $99.1 \%$ of healthy children in China remained HAV-immune 10 years after a two-dose vaccine schedule, with mean geometric antibody levels of $61.6 \mathrm{mIU} /$ $\mathrm{mL}$. Sharapov et al. [13] also found persistence of hepatitis A vaccine induced seropositivity in the same period of follow-up.

The HAV seropositive group had better control of HIV viral load, less decay of CD4+ T cells, and better clinical outcome during followup (Table 1). By contrast, all adolescents who lost HAV antibodies had a detectable viral load in the present evaluation. Suppressed HIV RNA levels were shown to be associated with durable seropositive responses after 41 weeks in HIV-infected children [14] and up to 6-10 years after HAV vaccination in HIV-infected adults [15]. 
Citation: Gouvêa AdFTB, de Moraes-Pinto MI, Miyamoto M, Pessoa SD, Machado DM, et al. (2014) Long-Term Persistence of Hepatitis AAntibodies in Pediatric HIV-Infected Patients after Primary Immunization: Association with Immunological Profile and Response to Revaccination. J AIDS Clin Res 5: 295. doi:10.4172/2155-6113.1000295

Page 5 of 6
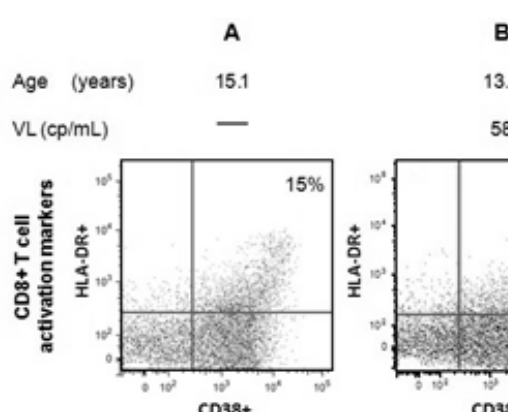

B C

C D

13.9

12.8

14.3

147

58078
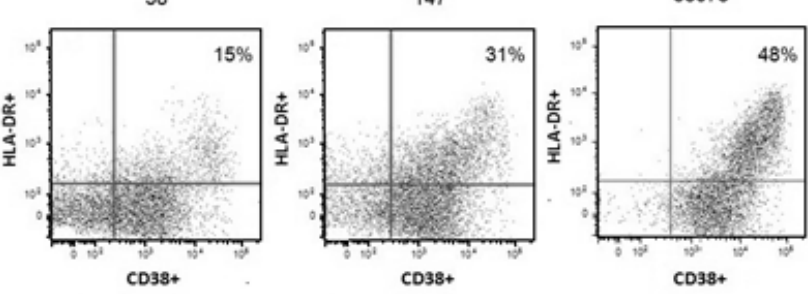

CD38+
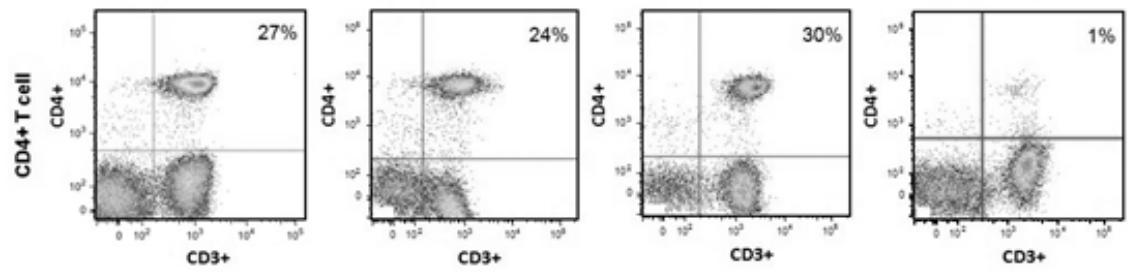

CD4+T cell

603
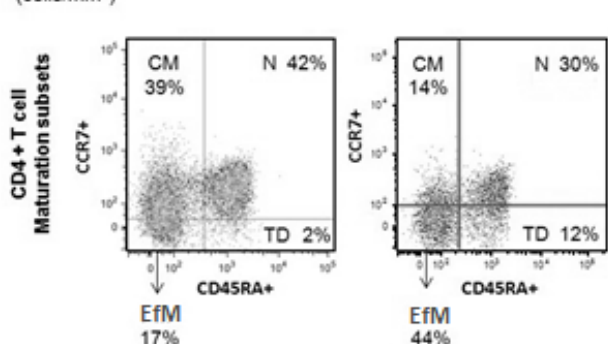

5

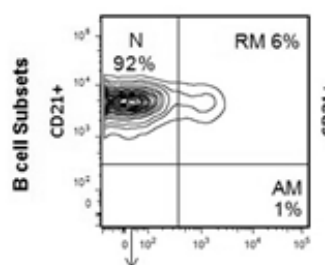

EfM


EfM

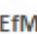

EfM
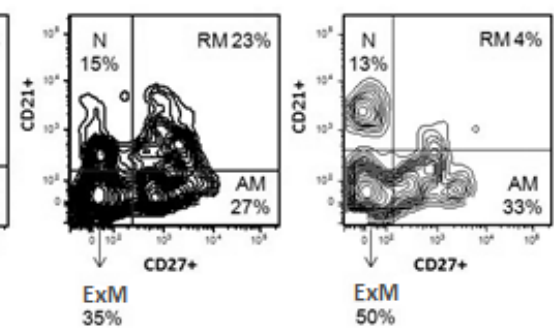

Figure 2: Cytometric flow chart of cell subpopulations of a healthy non-HIV-infected adolescent (A), a HIV-infected patient who maintained hepatitis A antibodies after 7 years (B), a HIV-infected patient who did not have hepatitis $A$ antibodies after 7 years but responded to the two doses of revaccination(C) and HIV-infected patient

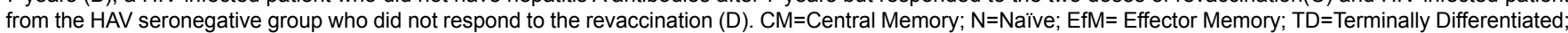
$\mathrm{RM}=$ Resting Memory; ExM=Exhausted Memory; $\mathrm{AM}=$ Activated Memory. Pseudo-color plot was used for T cells and contour plot, for B cells.

The sooner HIV-infected patients are immunized, the better, because if the patient has severe immunosuppression, he cannot respond to vaccination [16]. Among vertically HIV-infected children, the early initiation of HAART contributes to the maintenance of specific antibodies against common vaccine antigens [17]. Interestingly, in our study, all six adolescents who were not HAV-seropositive at assessment had initiated HAART after one year of age.

The present study found that higher median CD4+ T cell numbers before starting antiretroviral therapy, higher median nadir $\mathrm{CD} 4+\mathrm{T}$ cell counts, and higher median current $\mathrm{CD} 4+\mathrm{T}$ cell numbers were related to long-lasting HAV antibodies. In 2007, Ssewanyana et al. [18] showed that when children with low $\mathrm{CD} 4+\mathrm{T}$ cell counts have a higher proportion of activated CD4+ $\mathrm{T}$ cells, fewer CD4+ $\mathrm{T}$ cells may be available for differentiation into memory cells upon exposure to novel antigenic stimuli, such as vaccines.

HIV-infected adolescents who remained HAV seropositive had significantly less immune activation markers for CD4+T cells, CD8+T cells, and B cells. CD38 is known to be a predictor of prognosis in chronic infection [19]. In accordance with our results, Pessoa et al. [20] found higher immune activation markers, a lower CD4+ T cell percentage, and more frequently detectable HIV viral load in adolescents who did not respond to hepatitis $\mathrm{B}$ revaccination.

As shown in Table 2, absolute B cell values were lower in the HAV seronegative group compared with the HAV-seropositive group. Moir and Fauci [11] indicated that high levels of HIV viraemia are associated with activated mature B cells and exhausted memory B cells. The same was observed in the group without detectable HAV antibodies.

The six adolescents who did not have detectable antibodies to HAV were revaccinated with two doses of the same hepatitis A vaccine $\left(\right.$ Havrix $\left.^{\oplus}\right)$. Surprisingly, five adolescents responded to revaccination, with $\mathrm{HAV}$ antibodies $>1,000 \mathrm{mIU} / \mathrm{mL}$ in two of them. 
Citation: Gouvêa AdFTB, de Moraes-Pinto MI, Miyamoto M, Pessoa SD, Machado DM, et al. (2014) Long-Term Persistence of Hepatitis AAntibodies in Pediatric HIV-Infected Patients after Primary Immunization: Association with Immunological Profile and Response to Revaccination. J AIDS Clin Res 5: 295. doi:10.4172/2155-6113.1000295

Page 6 of 6

The only patient who did not respond to revaccination had been hospitalized with a diagnosis compatible with neurotoxoplasmosis. He had a high HIV viral load, very low CD4+ T cell counts, high expression of activation markers, and high percentages of exhausted and activated memory B cells (Figure 2, patient D).

It is now well established that the production of memory B and $\mathrm{T}$ cells is of clear importance to the maintenance of immunologic memory after vaccination [21]. Weinberg et al. [22] highlighted the importance of T-B cell interactions in the response to HAV vaccination in HIV-infected children and adolescents. The authors found that viral load control and a high percentage of B cells were positively associated with good response to HAV immunization. Moreover, they noticed a significant association between the percentage of CD19+CD21+CD27+ memory B cells and response to vaccination.

The small sample size was a limitation of the present research. Despite that, a clear association between the immune status of HIVinfected adolescents and both the persistence of HAV antibodies after primary immunization and response to revaccination could be observed.

The evaluation of memory $B$ cell subsets showed that the maintenance of HAV antibodies 7 years after immunization occurred when resting memory $B$ cells were predominant. As the percentage of activated memory B cells and exhausted memory B cells increased, the patient tended to lose HAV primary response and even did not respond to the revaccination (Figure 1B).

In summary, the present data showed that the vast majority of HIVinfected children can maintain HAV antibodies for at least 7 years if immunized with HAV vaccine while still not presenting severe clinical or immunologic signs (CDC categories $\mathrm{C}$ or 3 ). Even those who did not maintain antibodies can respond to revaccination 7 years after primary immunization. Both antibody maintenance and the response to revaccination are closely associated with low immune activation and adequate levels of CD4+ T and B cells. More studies are necessary to assess the long-term persistence of antibodies to different vaccines both after primary immunization and revaccination in vertically HIVinfected children and adolescents.

\section{Support Statement}

This study was funded by Fundação de Amparo à Pesquisa do Estado de São Paulo (FAPESP), Brazil: 09/17275-7

\section{References}

1. Sutcliffe CG, Moss WJ (2010) Do children infected with HIV receiving HAART need to be revaccinated? Lancet Infect Dis 10: 630-642.

2. Scott S, Mossong J, Moss WJ, Cutts FT, Cousens S (2008) Predicted impact of the HIV-1 epidemic on measles in developing countries: results from a dynamic age-structured model. Int J Epidemiol 37: 356-367.

3. Ximenes RA, Pereira LM, Martelli CM, Merchán-Hamann E, Stein AT, et al. (2010) Methodology of a nationwide cross-sectional survey of prevalence and epidemiological patterns of hepatitis A, B and C infection in Brazil. Cad Saude Publica 26: 1693-1704.

4. Kim YJ, Lee HS (2010) Increasing incidence of hepatitis A in Korean adults. Intervirology 53: 10-14.

5. Ministério da Saúde (2006) Manual dos centros de referência para imunobiológicos especiais. Ministério da Saúde, Secretaria de Vigilância em Saúde. Departamento de Vigilância Epidemiológica.

6. Gouvea AF1, De Moraes-Pinto MI, Ono E, Dinelli MI, Machado DM, et al. This article was originally published in a special issue, Vaccine research: HIV handled by Editor(s). Dr. Marc Van Regenmortel, University of Strasbourg, France
(2005) Immunogenicity and tolerability of hepatitis A vaccine in HIV-infected children. Clin Infect Dis 41: 544-548.

7. Centers for Disease Control (1994) Revised classification system for human immunodeficiency virus (HIV) infection in children less than 13 years of age. MMWR 43: 1-10

8. American Academy of Pediatrics (2012) Human Immunodeficiency Virus Infection. In: Pickering LK, Backer CJ, Kimbelin DW, Long SS, (Eds.), Red Book: Report of the Committee on Infectious Disease. American Academy of Pediatrics, Elk Grove Village, IL: 418-439.

9. World Health Organization (2007) The WHO child growth standards. World Health Organization, Geneva, Switzerland.

10. American Academy of Pediatrics (2012) Hepatitis A. In: Pickering LK, Backe CJ, Kimbelin DW, Long SS (Eds.), Red Book: Report of the Committee on Infectious Disease. American Academy of Pediatrics, Elk Grove Village, IL, 361-369.

11. Moir S1, Fauci AS (2009) B cells in HIV infection and disease. Nat Rev Immuno 9: 235-245.

12. Bian GL1, Ma R, Dong HJ, Ni HX, Hu FJ, et al. (2010) Long-term clinical observation of the immunogenicity of inactivated hepatitis $A$ vaccine in children. Vaccine 28: 4798-4801.

13. Sharapov UM1, Bulkow LR, Negus SE, Spradling PR, Homan C, et al. (2012) Persistence of hepatitis A vaccine induced seropositivity in infants and young children by maternal antibody status: 10-year follow-up. Hepatology 56: 516522

14. Siberry GK1, Coller RJ, Henkle E, Kiefner C, Joyner M, et al. (2008) Antibody response to hepatitis $A$ immunization among human immunodeficiency virusinfected children and adolescents. Pediatr Infect Dis J 27: 465-468.

15. Crum-Cianflone NF, Wilkins K, Lee AW, Grosso A, Landrum ML, et al. (2011) Infectious Disease Clinical Research Program HIV Working Group. Longterm durability of immune responses after hepatitis A vaccination among HIVinfected adults. J Infect Dis 203: 1815-1823.

16. Rigaud M, Borkowsky W, Muresan P, Weinberg A, Larussa P, et al. (2008) Pediatrics AIDS Clinical Trials Group P1006 Team. - Impaired immunity to recall antigens and neoantigens in severely immunocompromised children and adolescents during the first year of effective highly active antiretroviral therapy. $\mathrm{J}$ Infect Dis 198: 1123-1130.

17. Rigaud M1, Borkowsky W, Muresan P, Weinberg A, Larussa P, et al (2008) Impaired immunity to recall antigens and neoantigens in severely immunocompromised children and adolescents during the first year of effective highly active antiretroviral therapy. J Infect Dis 198: 1123-1130.

18. Pensieroso S1, Cagigi A, Palma P, Nilsson A, Capponi C, et al. (2009) Timing of HAART defines the integrity of memory $B$ cells and the longevity of humoral responses in HIV-1 vertically-infected children. Proc Natl Acad Sci U S A 106: 7939-7944.

19. Ssewanyana I1, Elrefaei M, Dorsey G, Ruel T, Jones NG, et al. (2007) Profile of $\mathrm{T}$ cell immune responses in HIV-infected children from Uganda. J Infect Dis 196: 1667-1670.

20. Cao W1, Jamieson BD, Hultin LE, Hultin PM, Detels R (2009) Regulatory cell expansion and immune activation during untreated HIV type 1 infection are associated with disease progression. AIDS Res Hum Retroviruses 25: 183-191.

21. Pessoa SD1, Miyamoto M, Ono E, Gouvêa AF, de Moraes-Pinto MI, et al. (2010) Persistence of vaccine immunity against hepatitis $B$ virus and response to revaccination in vertically HIV-infected adolescents on HAART. Vaccine 28 : 1606-1612.

22. Pichichero ME (2009) Booster vaccinations: can immunologic memory outpace disease pathogenesis? Pediatrics 124: 1633-1641.

23. Weinberg A, Huang S, Fenton T, Patterson-Bartlett J, Gona P, et al. (2009) IMPAACT P1008 Team. Virologic and immunologic correlates with the magnitude of antibody responses to the hepatitis A vaccine in HIV-infected children on highly active antiretroviral treatment. J Acquir Immune Defic Syndr 52: $17-24$ 